EDITORIAL

\title{
Post-socialist Revolutions of Intimacy: An Introduction
}

\section{Yulia Gradskova $^{1}$ (D) Alexander Kondakov ${ }^{2,3}$ - Maryna Shevtsova ${ }^{4}$}

Published online: 31 January 2020

(c) Springer Science+Business Media, LLC, part of Springer Nature 2020

\begin{abstract}
During the past decade, the states situated on the territory of the former Soviet Union and in Eastern Europe have made newspaper headlines around the world for topics on gender and sexuality: it seems that each step towards gender equality and inclusive sexual citizenship in the region has been accompanied by counter-actions on different scales. In what way is the present day of appropriate legislation and recent backlash connected to the legacies of regulations of gender relationships, intimacies, and sexualities under state socialism? What role do economic, political, and educational changes that took place in the region in the 1990s play in these developments? And finally, can we speak about certain similarities between discourses on sexuality and intimacy in the "West," on the one hand, and in post-Soviet and East European countries, on the other? Reflecting on current changes in post-socialist societies, the authors of this special issue give their own answers to these questions.
\end{abstract}

Keywords Intimacy $\cdot$ LGBTI $\cdot$ Sexual education $\cdot$ Sexual culture $\cdot$ Post-Soviet countries $\cdot$ Sexuality $\cdot$ Eastern Europe and Russia

During the past decade, the states situated on the territory of the former Soviet Union and in Eastern Europe have made newspaper headlines around the world for topics on gender and sexuality (Edenborg 2017). Reinforcing a clear-cut divide between East and West in Europe, some of them banned or violently crushed LGBT pride-festivals, attempted to restrict abortion, and in various other ways interfered in the intimate spheres of gender and sexuality through law and governmental policies (Wilkinson 2014; Kuhar and Paternotte 2017; Essig and Kondakov 2019). To give a few examples, in Poland, the ruling conservative Law and Justice party that gained

Yulia Gradskova

yulia.gradskova@sh.se

1 Södertörn Unniversity, Huddinge, Sweden

2 University College Dublin, Belfield, Dublin, Ireland

3 Aleksanteri Institute of the University of Helsinki, Helsinki, Finland

4 Lund University, Lund, Sweden 
a majority in the parliament has joined efforts with the Church and since 2016 has been trying to introduce a full ban on abortion (Yatsyk 2019). It is worth noting that Poland already has one of the strictest abortion laws in the EU with termination permitted only under three conditions: threat to the mother's life, fetal abnormality, or when pregnancy resulted from incest or rape. A new law now in the works proposes to imprison women seeking to get an abortion as well as those doctors who performed the procedure (Roache 2019). In Russia, the notorious law banning socalled "gay-propaganda" was adopted at the federal level in 2013 and, notwithstanding strong critique coming from international organizations and institutions, the law remains valid (Persson 2015; Human Rights Watch 2018). While these seem to be among the most shocking and well-known examples, there are other disturbing tendencies in the region. Although every year Equality Marches gather more and more people in Kyiv, Ukraine, right-wing forces, together with religious groups, have for years been blocking adoption of the Istanbul convention (2011) dealing with gender violence and protests against introducing sexual orientation and gender identity into the comprehensive anti-discrimination law (Martsenyuk 2012; Lavryk 2015). In Georgia, the situation with the adoption of the legal documents to protect rights of LGBTI people looks better. Yet, as the analysis offered by Tamar Tolardava and Dmitrii Tolkachev in this special issue demonstrates, implementation of these laws is far from perfect. In other words, it seems that each step towards gender equality and inclusive sexual citizenship in the region has been accompanied by counter-actions on different scales. The effect of these counter-actions depends on the position taken by the national government as well as on the role that international organizations and institutions play in a given country (Ayoub 2016).

How can these events be explained? In what way is the present day of inappropriate legislation and recent backlash connected to the legacies of regulations of gender relationships, intimacies, and sexualities under state socialism? What role do economic, political, and educational changes that took place in the region in the 1990s play in these developments? And finally, can we speak about certain similarities between discourses on sexuality and intimacy in the "West," on the one hand, and in post-Soviet and East European countries, on the other? Reflecting on current changes in post-socialist societies, the authors of this issue give their own answers to these questions.

A growing body of literature has recently emerged that discusses the so-called "political homophobia," a purposeful strategy employed by state actors to use politics of othering and scapegoating against vulnerable groups, in this case, LGBTI people (Weiss and Bosia 2013; Sperling 2014; Healey 2018; Buyantueva and Shevtsova 2019). Such politics is usually embedded in the state- and nation-building processes and creates conservative political alliances against change (Mole 2016; Moss 2017; Sleptcov 2017, 141). A good example that relates to both gender and sexuality is Russia's efforts to protect traditional family values from "Western influence" that allegedly tries to destroy them (see, Muravyeva 2014). This tendency is not unique to Russia, though. Roman Kuhar and Aleš Zobec (2017) study anti-gender campaigns across Europe and argue that ongoing resistance to social change should not be interpreted as a continuation of previously existing forms of opposition to sexual citizenship. Instead, they suggest that these counter-actions are new types of 
mobilization and of discourses that target wider audiences than just those nostalgic for the (socialist) past (Ibid, 31). In the case of Hungary, for example, anti-gender discourse is just one of the possible rhetorical frames that current government uses, together with the anti-migrant narratives, for political polarization (Peto and Kovats 2017). There, anti-gender rhetoric fits a government's objectives, because it has the potential for mass mobilization in bringing into the conversation previously uninvolved segments of the society. In other words, political homophobia and antigender rhetoric mix with many other hate themes that engage various social groups that politicians may further exploit. The diversity of existing explanations of these processes shows that the backlash that we are witnessing is a focal point of attention that still needs to be further explored.

This special section aims at reviewing, analyzing, and explaining at least some of the current paradoxes and conflicts mentioned above. It combines historical perspective with the analysis of contemporary issues to explore challenges and products of post-socialist changes in the sphere of gender and sexuality across post-Soviet and Eastern European states. In order to do this, we focus not on gender and sexuality per se, but on intimacy - the concept that includes a variety of close social relationships in connection to rights, belonging, and citizenship (Plummer 2003; Giddens 2008; Aavik 2019). According to Anthony Giddens, the modernization of society leads to the transformation of intimacy, which in turn has a drastic impact on the transformation of gender orders (Giddens 2008). In his seminal work, he looks at Western societies to argue this case. However, postcolonial, queer, and disability studies questioned many assumptions underpinning historical Eurocentric interpretations of intimacy (Essig 1999; Tlostanova 2010; Hammack et al. 2019; Phillips 2011; Hartblay 2014). Authors of this issue offer insights from their studies of postsocialist societies to continue these lines of inquiry. Thus, they address the changes in norms and practices of intimacy in several post-socialist countries questioning the causes of the current political developments and their implications for the region. Our aim is to open an academic conversation about these drastic changes within a historically short period from the 1990s to the 2010 s.

\section{What We Already Know About Revolutions of Intimacy}

The scholarship on Russia stressed revolutionary changes in the sphere of intimacy after the 1917 revolution; Yulia Gradskova continues this line of thinking in her article in this issue. Both Igor Kon (2010) and Dan Healey (2001) suggested that revolutionary transformations took place in this sphere under initial Bolshevik policies. Among them were a declaration of equal rights for men and women in family life, divorce, abortion and the decriminalization of homosexual relationships. Nonetheless, a much more totalitarian version of communism, the Stalinist regime, put an end to most of these changes by re-criminalization of male homosexuality in 1934 and an abortion ban in 1936 among other restrictive policies. According to Anna Rotkirch and Anna Temkina, another transformation of intimacy started already in the late Soviet period in the 1970s as sexual practices of people were changing by becoming more diverse (Rotkirch 2000; Temkina 2010). As for other 
state socialist countries of the Eastern European region, they had significant differences with respect to public discourse on sexuality and sex education. According to Kateřina Lišková (2018), until the 1960s, silence surrounded topics on sexuality in the public sphere in Czechoslovakia, but in the 1970s and 1980s, issues of sexuality were openly discussed. In Czechoslovakia and in the East German Democratic Republic (the GDR), the field of sexology developed and was partly a state supported science in the 1970-1980s — not least in the hopes to increase the birthrate and to keep young people in the system. In particular, as Josie McLellan contended, East German sexologists showed inflated statistics on female orgasm, indicating that "East Germans were the global leaders in the field of sexual satisfaction" $(2011,17)$. One of the articles in this special section-by Renata Ingbrant—discusses contradictions of the development of sexology in another Eastern European country-Poland. In the USSR, Igor Kon (2010) sees drastic changes only in the late 1980s when Perestroika and Glasnost made it possible to introduce the themes of sexuality into public discussions there. ${ }^{1}$ Francisca Stella (2015) and Kondakov (2019, 406-410) indicated a partial continuation of the trends in post-Soviet Russia rather than a complete rupture with the past. They studied alternative cultural public spaces for lesbian and gay citizens in Soviet and post-Soviet Russia and found many similarities between two epochs in the way people refer to sexuality and politics. It is especially important to take into account that the major change that was happening after the collapse of the USSR was the introduction of capitalist relations (Essig 1999). Hence, commercialization and commodification of sexuality took place in the 1990s and it implied that intimacies became an object of the market, while simultaneously remaining under the influence of state power (Swader and Obelene 2015, 245).

The fall of the Berlin wall (1989) and the dissolution of the Soviet Union (1991) are understood by many scholars as the beginning of the new revolutionary changes all over Eastern Europe. The transformation of intimacies there provoked many discussions, but also brought up different problems and periodization. Lišková, for example, made a distinction between the revolutionary character of changes with respect to love, sexuality, and gender equality in Czechoslovakia in the 1950s and the return of a more traditional discourse on women's role as mothers in the 1970s (2018, 255). Meanwhile, McLellan (2011) showed that liberalization of sexuality in the GDR in the 1960s was quite limited. Scholarship on queer communities in Eastern Europe also problematized the developmental paradigm that compares West and East. In particular, Robert Kulpa and Johanna Mizielinska suggested that in comparison to Western Europe, where the researchers used to see waves and sequences of development, Eastern Europe demonstrates a rather convoluted coincidence of different processes of changes in the intimate sphere (2011, 15-17). The existing research, however, leaves many gaps with respect to different aspects of changes in intimacy in the region. In particular, the geographical differences inside the Soviet Union or different countries of Eastern Europe, as well as class differences, are not regarded as much as they could have been. This suggests that there is a need for more in-depth studies of the post-socialist transformations of intimacy.

\footnotetext{
1 In a few Soviet cities, some consultation on sex-therapy appeared already in the 1980 s.
} 
For many years, countries of state socialism shared somewhat similar views with respect to gender and sexuality. For example, as mentioned above, all countries of the socialist bloc guaranteed the participation of women in the labor market from the very beginning (Salmenniemi and Adamson 2015), many providing abortion through the healthcare system into the late socialist period (Lennerhed 2016), ${ }^{2}$ and many granting divorce on demand (Goldman 1993). Moreover, this was at a time when, in the US, middle-class women were expected to stay at home rather than work (until at least the 1970s); in the Netherlands, abortion was not legalized until 1984; in the UK, people still cannot divorce simply by expressing their will to do so, without a lengthy period of separation. Certainly, all those achievements in the countries of state socialism did not come by default and did come at a cost. Thus, the Soviet government was the first to legalize abortion in 1920 only to have it criminalized again in the period 1936-1953 (Goldman 1993). The participation in the labor market for women, without cultural changes to gender roles, meant that women had to bare a double burden: they worked in the public sector for remuneration and then still held responsibilities for unsalaried domestic work in the home (Zdravomyslova and Temkina 2005). The researchers studying developments in the state socialist Eastern Europe often notice the conservative turn in gender policies in the 1960s, in particular, a special focus on women's domestic responsibilities in countries like Hungary and Czechoslovakia (see, Asztalos Morell 1999; Gradskova and Morell 2018; Lišková 2018).

As for the field of sexuality, Czechoslovakia, Hungary, East Germany, and Bulgaria decriminalized male homosexuality in the 1960s, earlier than many other countries in the "West." This did not lead to changes in the societal perception of homosexuality in these countries, though (on the GDR, see McLellan 2011, 118). Moreover, public activism for LGBT rights was problematic-just like any other activism - until the very end of state socialism and many gay and lesbian dissidents were under severe scrutiny of the secret police (Essig 1999; Kirchik 2013; Szulc 2018). The USSR - following a period of decriminalization of homosexuality after the Bolshevik 1917 revolution-criminalized male sexual intercourse in 1934 and this law continued to be in force until 1993 (Healey 2001). Besides, the USSR was reluctant to even have discussions of homosexuality in public (Alexander 2018). In Poland, by contrast, a strong and diverse field of sexology developed (see Ingbrant in this issue). Therefore, a conversation about gender and sexuality in the region is a complicated one, despite common assumptions that tend to emphasize a blackand-white picture. In terms of gender and sexuality, state socialism was not good or bad per se but was, in some significant ways, different from the developments in the "West" (Kulpa and Mizielinska 2011).

\footnotetext{
2 According to the Swedish historian Lena Lennerhed, some Swedish women in the early 1960s were traveling to the state socialist Poland in order to have abortions (Lennerhed 2016). However, in Romania, on the contrary, abortion was severely restricted between 1967 and the end of the socialist period.
} 


\section{Intimacy, Sexuality, and Revolutions}

How do we account for these peculiarities and contradictions? Major differences were not only found in those substantial socialist policies in the gender sphere that existed back then, but also in the different spatial structure that conditioned politics. In the "West," a sexual revolution occurred in the form of public expression of claims and concerns related to gender and sexuality, whereas in state-socialist countries a different kind of revolution emerged, that is, a revolution of intimacy that took place in the private sphere at about the same time. Communist governments tended to control public expressions and discourse through a rigorous regulation of what could be said or done publicly (Yurchak 2005). This produced an effect when, by the late years of state socialism, politics was dislocated into alternative spaces: "parallel with the official-public sphere there came into being another public sphere" (Voronkov and Chikadze 2003, 243; see also, Voronkov and Zdravomyslova 2002; Stella 2015, 114; Kondakov 2019). Therefore, people in state-socialist countries engaged in political argument, agitation, or political action in private spaces (individual apartments, for example), because what would be considered public by "Western" standards was totally occupied by ceremonies of the Communist Party (Kondakov 2014). Susan Gal describes this situation in socialist Hungary:

A parallel development (in this case tolerated although certainly not encouraged by the state) was the growth of small dissident political organizations, voluntary groups of various kinds including samizdat publication ventures. Again, these were understood by actors as "politics," and hence public [...]. Like production within the household, which was labeled and discussed under the rubric of the "second economy," this kind of politics was heavily theorized by those engaging in it. They considered this public-inside-the-private as a significant dissident gesture and famously called it "anti-politics." (Gal 2002, 88-89)

When conceptualizing sexual revolutions in the region, we offer to take this structure of space into account and see how political changes can be made without presenting public demands, but rather within the intimate space of privacy.

Therefore, we argue that talking about "sexual revolutions" in state socialist countries may be misleading, because this concept puts too much emphasis on making sexuality public in order to advance revolutionary changes. In our case, the changes had more of a private character and, hence, better fit to the concept of intimacy that does not imply public claims or political demands. If "sexual revolution" is applied to analyze changes in the spheres of gender and sexuality in state socialist countries, these countries may be seen as lagging behind, because very few changes there remain visible. Yet, such a view may miss important (revolutionary) transformations of intimacy that occurred a couple of decades before the collapse of the Socialist bloc. This is why we suggest referring to these transformations as "revolutions of intimacy," in order to cover a wider range of topics in the field and to account for the peculiar structure of space in the region. Such a conceptual move should be helpful in making sense of current developments related to gender and 
sexuality in the post-Soviet and Eastern European countries. If we take this argument into consideration, we may suggest that revolutions of intimacy go on there, although still obscured by the visible surface of political discourse that represents a very different picture from the one that occurs underground.

Our conceptualization of social transformations does not mean to suggest, however, that state-Socialist countries were so very different from many other states in Europe at the time-they all had their own peculiarities. However, employment of only one concept, the "sexual revolution," does imply the drastic difference: whereas changing meanings of sexuality had been so evident for France or the USA since this revolution, the state socialist countries, on the contrary, seemed to remain untouched (because no changes were seen in the public eye). Moreover, the post-Soviet and Eastern European countries still remain captive to their stagnation with respect to acceptance of the diversity of intimacies. The contribution by Irina Gewinner in this volume shows that many Russian-speaking migrants from the post-Soviet countries to Germany have rather normative ideas about teenage sexuality, for example. Yet, "revolutions of intimacy" offer a more accurate picture. This concept just shifts the register by suggesting that when transformations are not seen, this does not necessarily mean that they are not happening at all. In this sense, consider this issue's article by Elena Iarskaia-Smirnova and Volha Verbilovich, who show slow changes occurring with respect to the public discourse on disability and sexuality in contemporary Russia. In a way, "revolutions of intimacy" and the Western "sexual revolutions" are two ways of referring to similar events, but happening on different levels. This helps to understand nuances of the situation of intimacy as compared to sexuality. We want readers to consider this, when going through the texts of this special section.

\section{Intimacies in Post-socialist Space: Contributions to this Special Issue}

The articles brought together in this special issue provide the reader with an overview of the discussion of intimacy across countries and disciplines. The authors aim to explore the processes of overcoming, transforming, and negotiating the communist/Soviet sexuality regimes in Eastern Europe and the post-Soviet space in terms of both similarities and differences. How is the memory of these changes preserved in the context of new repressive sexuality regimes? To what extent is it possible to speak about sexual revolution(s) as a part of broader emancipatory social transformations in the space of post-Socialism? What are the current developments with respect to sexuality in the Baltic States, Russia, Eurasia and Eastern Europe?

Renata Ingbrant connects the recent backlash in Poland against gender equality and LGBT people to the recently emerged public interest in 40-year-old works on sexology by Michalina Wisłocka. Ingbrant's article Michalina Wisłocka's "The Art of Loving" and the Legacy of Polish Sexology offers the readers a thorough account on the development of Polish sexology and, especially, on social and cultural implications of works by Wisłocka, who is considered one of its major representatives in the 1970s. Possibly "progressive" for her own times, this scholar's writings nowadays can be considered rather outdated as she was promoting a particular mix of 
much needed knowledge on sexology with strict notions of binary gender roles as a foundation for one's satisfactory sexual life. Renata Ingbrant sheds light on some quite controversial parts of Wisłocka's book where the author discusses abortion, rape, and female subordination. During the last several years, Poland has witnessed numerous restrictions, or attempts at restricting women's rights, such as an abortion ban, an ongoing war on the so-called "gender ideology," the refusal to introduce sex education, the violation of LGBTI people's rights, just to mention a few things on this far-from-exhaustive list. The awakening of interest in the literature promoting sex education, pleasure and autonomy in this context, and-in spite of all the limitations of the book by Wisłocka-could be seen as a way of subverting and questioning the current social mood.

Yulia Gradskova in her article, Personal is Not Political? The Sexual Self in Russian Talk Shows of the 1990s, explores how the sexual self was constructed by the participants of two popular talk shows broadcast by Russian television in the 1990s. Gradskova uses talk shows to address the processes of sexual liberalization and transformation of sexual culture in Russia two decades ago and questions the potential that this form of TV production had for politicization of the issues of gender and sexuality. Based on her research results, the author argues that, seen as novel and groundbreaking at the time, the programs were not, in fact, envisioned for collective political mobilization, but rather aimed at encouraging slow change in public views with regard to the sphere of one's private life. Such public discussion, therefore, was at best educational but failed to mobilize social movements or solidarities of a political character. Furthermore, nowadays in Russia, it is remarkable that some of the public figures connected to those talk shows in the 1990s have currently chosen to publicly readdress the topics of sex, gender, private life, and family relations, following a rather traditional agenda. It may serve as a reflection of the recent public trends emphasizing the importance of family values, binary gender roles, and heteronormativity.

In their article Talking about Sexual Violence in Post-Maidan Ukraine: Analysis of the Online Campaign \#IAmNotAfraidToSayIt Tamara Martsenyuk and Sarah D. Phillips analyze reactions and implications coming from the now famous online (hashtag) campaign \#ЯНеБоюсьСказати (\#IAmNotAfraidToSayIt) that started in 2016 in Ukraine and continued in Russia, Belarus and Kazakhstan, as well as in the United States, Germany, and Israel. The authors argue that the campaign served as a kind of a litmus test. On the one hand, it triggered a public dialogue on gender, sexuality, and sexual violence. Yet, on the other hand, it also revealed how ambivalent Ukrainian society still is on this issue and the ongoing presence of the so-called "anti-gender" discourses and practices among some politicians and activists. These discourses and practices have real effects, resulting in key discussions. Even more so, attempts at introducing legal measures to counter sexual violence and sanction perpetrators, stumbling over language and proving inefficient, when important terms like 'gender' or 'sexual orientation' and 'gender identity' are excluded from these discussions. In spite of these setbacks, Martsenyuk and Phillips see great potential for online space to serve as a platform for "nascent activism and positive social and political change." They are very realistic, however, pointing out that there is still 
much to be done in Ukraine for sexual violence to be criminalized and for public attitudes towards gender-based and sexual violence to be shifted.

In It's no longer a taboo', is it? Stories of intimate citizenship of people with disabilities in today's Russian public sphere, Elena Iarskaia-Smirnova and Volha Verbilovich discuss social control and manipulations over social identities of people with disabilities in modern Russian society. The authors question the production of personal stories of sexuality, especially those made public through media narratives, film images, and stories that were published in social media. The core finding of such an examination is that the presentation of "disabled sexuality" in Russian society reflects the revival of conservative ideology in the region. Iarskaia-Smirnova and Verbilovich demonstrate that the sexuality of persons with disabilities is often portrayed in grotesque and medicalized images of usually male sexual experiences and rarely "normal" heterosexuality of such people is mentioned, while all non-heteronormative identities are ignored or silenced. This sheds some light on the ways in which intimate citizenship in Russia is framed through mental and bodily otherness. Reflecting on resisting prejudices in the society that still dominate in the media discourse, the authors look for ways for people with disabilities to deconstruct and reconstruct their sexual and gender identities. In the article by Martsenyuk and Phillips, the personal was becoming political through making public intimate stories of sexual violence and harassment through the \#IAmNotAfraidToSayIt campaign and, brought together, gained the potential for collective action. Interestingly enough, in the article by Iarskaia-Smirnova and Verbilovich, personal stories of the body, gender, and the sexuality of people with disabilities became political when their stories were taken into the public sphere with the aim of redefining normalcy, recognition and fair representation.

Dmitrii Tolkachev and Tamar Tolordava in their piece Shared past, different future? Russian and Georgian authorities discourses about homosexuality analyze institutional changes and public discourses in two post-Soviet countries that have chosen different ways of framing homosexuality as a legal issue. Indeed, both countries preserve conservative social values with rather homophobic attitudes against the backdrop of the growing presence of the Orthodox Church. Yet in one of them, in Georgia, legal reforms to improve, albeit on a declaratory level, the life conditions for LGBTI people, while in Russia the infamous law banning the so-called "propaganda of homosexuality" was adopted. The authors argue that the developments in Georgia were the consequence of the strong presence of the European Union in the country. According to them, the fact that anti-discrimination legislation was adopted, despite homophobic sentiments shared by the majority of citizens, demonstrates that a strong political will may be enough to at least make first legal steps in protecting minority rights. It is the implementation, though, that is lacking. In the case of Russia, attitudes towards homosexuality are also at the core of relations with the "West" but, if Georgia is seeking approximation, the government of Vladimir Putin makes homosexuality one of the underlying reasons for the confrontation. The whole discourse is constructed around the idea of so-called "traditional family values" versus homosexuality inevitably connected with pedophilia, perversion and other kinds of "deviations." 
Finally, Irina Gewinner is concerned with the post-socialist individual cultural legacy, perceptions of gender norms, and of the sexuality of Russian-speaking migrant women in Germany. In her article Gender norms, sexuality and post-Socialist identity: Does migration matter? the author questions the dominant norms of "maturity" regarding such issues as fertility, sexuality, abortion, and childbearing for Russian-speaking migrants in Germany, who grew up in the (post-)Socialist period. Gewinner argues that attitudes still prevailing among Russian-speaking women are based on making direct links between love and sex. In such a context, sex can only be justified through serious intentions to create a family with a male partner, while all other forms of sexuality are stigmatized and marginalized. The second part of Gewinner's argument refers to the notion of a "good mother" among Russian-speaking women in Germany, where a "good mother" is expected to raise good and prudent future adults. One of the major implications of this research project results is the preservation of cultural patterns among the migrant population, in the present case, pointing to a deep path-dependency and post-Soviet legacy. This claim gains even more importance taking into consideration the revival of traditional views and the resurgence of patriarchy in the German public sphere with the backlash against gender equality and LGBT rights and the growing presence of right-wing groups across Europe.

Since studies on sexuality in and about Eastern Europe and post-Soviet countries are still limited, this selection of articles should be seen as reflections of those inside regional scholarship, which, we hope, other researchers and scholars working on these topics will find valuable and sensitive to their local meanings and connotations.

Acknowledgements The special section was begun after the two-day workshop "Revolutions of Intimacy: Sexuality, Rights and Backlash" that took place at the Center for Baltic and East European Studies (CBEES) at Södertörn University (Sweden) and in the Nordic Museum in October 2018. The workshop was supported by the Swedish Bank Jubilee Fund (Riksbankens Jubileumsfond) and by CBEES and the editors want to express their gratitude for the financial support. We would also like to thank all the authors who contributed to this special issue for sharing their work with us as well as to prof. Lena Lennerhed and assoc. prof. Marianna Muravyeva for their comments on early version of this paper. We thank the Aleksanteri Institute of the University of Helsinki for their support of the issue.

Ethical Statement This introductory article did not receive any specific funding. The authors declare that they do not have conflict of interests. This article does not contain any studies with human participants or animals performed by any of the authors.

\section{References}

Aavik, K. (2019). Negotiating uncertainty: Sexual citizenship and state recognition of same-sex partnerships in Estonia. In R. Buyantueva \& M. Shevtsova (Eds.), LGBTQ+activism in Central and Eastern Europe. Resistance, representation and identity. Basingstoke: Palgrave MacMillan.

Alexander, R. (2018). Sex education and the depiction of homosexuality under Khrushchev. In M. Ilic (Ed.), The Palgrave handbook of women and gender in twentieth-century Russia and the Soviet Union (pp. 349-364). Basingstoke: Palgrave.

Asztalos Morell, I. (1999). Emancipation's dead-end roads. Study in the rise and development of the Hungarian model for agriculture and gender (1956-1989). Uppsala: Acta Uppsalienses. 
Ayoub, P. M. (2016). When states come out: Europe's sexual minorities and the politics of visibility. Cambridge: Cambridge University Press.

Buyantueva, R., \& Shevtsova, M. (Eds.). (2019). LGBTQ+activism in Central and Eastern Europe. Resistance, representation and identity. Basingstoke: Palgrave MacMillan.

Edenborg, E. (2017). Politics of visibility and belonging: From Russia's "Homosexual Propaganda" laws to the Ukraine War. London: Routledge.

Essig, L. (1999). Queer in Russia. A story of sex, self, and the other. Durham: Duke University Press.

Essig, L., \& Kondakov, A. (2019). A cold war for the twenty-first century: Homosexualism vs. Heterosexualism. In R. Mole (Ed.), Soviet and post-Soviet sexualities (pp. 79-102). New York: Routledge.

Gal, S. (2002). A semiotics of the public/private distinction. Differences: A Journal of Feminist Cultural Studies, 13(1), 77-95.

Giddens, A. (2008). The transformation of intimacy: Sexuality, love and eroticism in modern societies. Cambridge, MA: Polity.

Goldman, W. (1993). Women, the state and revolution. Soviet family policy and social life, 19171936. Cambridge: Cambridge University Press.

Gradskova, Y., \& Morell, I. (2018). Gendering postsocialism. Old legacies, new hierarchies. London: Routledge.

Hammack, Ph, Frost, D., \& Hughes, S. (2019). Queer intimacies: A new paradigm for the study of relationship diversity. Journal of Sex Research, 56(4-5), 556-559.

Hartblay, C. (2014). Welcome to sergeichburg: Disability, crip performance, and the comedy of recognition in Russia. The Journal of Social Policy Studies, 12(1), 111-125.

Healey, D. (2001). Homosexual desire in revolutionary Russia: The regulation of sexual and gender dissent. Chicago: Chicago University Press.

Healey, D. (2018). Russian homophobia from Stalin to Sochi. New York: Bloomsbury.

Human Rights Watch. (2018). No Support. Russia's "Gay Propaganda” Law Imperils LGBT Youth. December 11, 2018. Retrieved September 20, 2019, from https://www.hrw.org/repor t/2018/12/11/no-support/russias-gay-propaganda-law-imperils-lgbt-youth.

Kirchik, J. (2013). Documentary Explores Gay Life in East Germany. Spigel Online. 15.02. Retrieved September 19, 2019, from https://www.spiegel.de/international/germany/documentary-exploresgay-and-lesbian-oppression-in-east-germany-a-883707.html.

Kon, I. (2010). Klubnichka na berezke. Seksualnaia kultura v Rossii [Strawberry on a Birch Tree: Sexual culture in Russia]. Moscow: Vremia.

Kondakov, A. (2014). The silenced citizens of Russia: Exclusion of non-heterosexual subjects from rights-based citizenship. Social \& Legal Studies, 23(2), 151-174.

Kondakov, A. (2019). Rethinking the sexual citizenship from queer and post-Soviet perspectives: Queer urban spaces and the right to the socialist city. Sexualities, 22(3), 401-417.

Kuhar, R., \& Paternotte, D. (Eds.). (2017). Anti-gender campaigns in Europe: Mobilizing against equality. London: Rowman and Littlefield.

Kuhar, R., \& Zobec, A. (2017). The anti-gender movement in Europe and the educational process in public schools. CEPS Journal, 7(2), 29-46.

Kulpa, R., \& Mizielinska, J. (2011). De-centring western sexualities. Farnham: Ashgate.

Lavryk, D. (2015). Gomofobiia V Ukraini: Tendentsii postmaidannoho periodu [Homophobia in Ukraine: Post-Maidan Trends], Commons: Journal of Social Criticis. 18.05.2018. Retrieved September 20, 2019, from http://commons.com.ua/gomofobiya-v-ukrayini/.

Lennerhed, L. (2016). The Poland affair. Baltic Worlds. Retrieved September 19, 2019, from http:// balticworlds.com/the-poland-affair/.

Lišková, K. (2018). Sexual liberation, socialist style. Communist Czechoslovakia and the science of desire, 1945-1989. Cambridge: Cambridge University Press.

Martsenyuk, T. (2012). The state of the LGBT community and Homophobia in Ukraine. Problems of Post-Communism, 59(2), 51-62.

McLellan, J. (2011). Love in the time of communism: Intimacy and sexuality in the GDR. Cambridge: Cambridge University Press.

Mole, R. (2016). Nationalism and Homophobia in Central and Eastern Europe. In K. Slootmaeckers, H. Touquet, \& P. Vermeersch (Eds.), The EU enlargement and gay politics. Gender and politics (pp. 99-121). London: Palgrave Macmillan.

Moss, K. (2017). Russia as the Savior of European Civilization: Gender and the geopolitics of traditional values. In R. Kuhar \& D. Paternotte (Eds.), Anti-gender campaigns in Europe: Mobilizing against equality (pp. 195-214). London: Rowman and Littlefield. 
Muravyeva, M. (2014). Traditional values and modern families: Legal understanding of tradition and modernity in contemporary Russia. The Journal of Social Policy Studies, 12(4), 625-638.

Persson, E. (2015). Banning "homosexual propaganda": Belonging and visibility in contemporary Russian media. Sexuality and Culture, 19(2), 256-274.

Peto, A., \& Kovats, E. (2017). Anti-gender discourse in Hungary: A discourse without a movement? In R. Kuhar \& D. Paternotte (Eds.), Anti-gender campaigns in Europe: Mobilizing against equality (pp. 117-131). London: Rowman and Littlefield.

Phillips, S. (2011). Disability and mobile citizenship in postsocialist Ukraine. Bloomington: Indiana University Press.

Plummer, K. (2003). Intimate citizenship: Private decisions and public dialogues. Seattle: University of Washington Press.

Roache, M. (2019). Poland is trying to make abortion dangerous, illegal, and impossible. Foreign Policy. 08.01.2019. Retrieved September 20, 2019, from https://foreignpolicy.com/2019/01/08/poland-istrying-to-make-abortion-dangerous-illegal-and-impossible/.

Rotkirch, A. (2000). The man question: Loves and lives in late 20th century Russia. Helsinki: University of Helsinki.

Salmenniemi, S., \& Adamson, M. (2015). New heroines of labour: Domesticating post-feminism and neoliberal capitalism in Russia. Sociology, 49(1), 88-105.

Sleptcov, N. (2017). Political homophobia as a state strategy in Russia. Journal of Global Initiatives: Policy, Pedagogy, Perspective, 12(1), 9.

Sperling, V. (2014). Sex, politics, and Putin: Political legitimacy in Russia. New York: Oxford University Press.

Stella, F. (2015). Lesbian lives in Soviet and post-Soviet Russia. Basingstoke: Palgrave.

Swader, Ch., \& Obelene, V. (2015). Post-Soviet intimacies: An introduction. Sexuality and Culture, 19, $245-255$.

Szulc, L. (2018). Transnational homosexuals in communist Poland: Cross-border flows in gay and lesbian magazines. Cham: Palgrave Macmillan.

Temkina, A. (2010). Sexualnaia zhizn zhenshchiny mezhdu podchineniem i svobodoi. St.Petersburg: EUSP.

Tlostanova, M. (2010). Gender epistemologies and Eurasian borderlands. Basingstoke: Palgrave Macmillan.

Voronkov, V., \& Chikadze, E. (2003). Different generations of Leningrad Jews in the context of public/ private division: Paradoxes of ethnicity. In R. Humphrey, R. Miller, \& E. Zdravomyslova (Eds.), Biographical research in Eastern Europelaltered lives and broken biographies (pp. 239-262). Aldershot: Ashgate.

Voronkov, V., \& Zdravomyslova, E. (2002). The informal public in Soviet society: Double morality at work. Social Research, 69(1), 49-69.

Weiss, M. L., \& Bosia, M. J. (Eds.). (2013). Global homophobia: States, movements, and the politics of oppression. Urbana: University of Illinois Pres.

Wilkinson, C. (2014). Putting 'traditional values' into practice: The rise and contestation of anti-homopropaganda laws in Russia. Journal of Human Rights, 13, 363-379.

Yatsyk, A. (2019). Biopolitical conservatism in Europe and beyond: The cases of identity-making projects in Poland and Russia. Journal of Contemporary European Studies. https://doi.org/10.1080/14782 804.2019.1651699.

Yurchak, A. (2005). Everything was forever, until it was no more: The last Soviet generation. Princeton, NJ: Princeton University Press.

Zdravomyslova, E., \& Temkina, A. (2005). Gendered citizenship in Soviet and post-Soviet societies. In V. Tolz \& S. Booth (Eds.), Gender and nation in contemporary Europe (pp. 96-115). Manchester: Manchester University Press.

Publisher's Note Springer Nature remains neutral with regard to jurisdictional claims in published maps and institutional affiliations. 